\title{
Islam as World Religion in Northern Mali
}

\begin{abstract}
In 2012, northern Mali seceded from the rest of the country under the leadership of secessionist and Islamist groups. This, and subsequent events, have been interpreted, broadly speaking, in two ways. First, as a result of the unchecked influence of external actors representing 'global jihad' on a country whose Islamic practice had until then been described as 'moderate'. Second, allegiance to Islamist groups was seen as a strategy in local power struggles. Without wanting to invalidate the latter interpretation, this chapter asks what would happen if we took the Islamic rhetoric put forward by various actors in northern Mali seriously. This implies understanding Islam in the region both in local and in transregional terms, and placing it within a narrative not of radical rupture, but of continuity. Contemporary tensions between local conflicts and universal notions of justice, legitimacy and belonging, have in fact a long and variegated history in the area.
\end{abstract}

\section{Introduction}

When large parts of northern Mali seceded from the country under the leadership of Islamist groupings in early 2012, there was an immediate tendency in the European media to blame this on external influences that had, in the space of a decade or less, apparently led to the 'radicalisation' of the 'traditionally moderate' Islam practiced in the area. ${ }^{1}$ As a widely-cited and generally well-informed analysis of events stated in 2013, the "open sore" of conflict-ridden and poorly governed northern Mali had become "infected by foreign Salafi ideas and mujahideen, and by trans-national networks of organised crime". ${ }^{2}$ Others soon proposed an alternative reading. They suggested that the reference to 'radical Islam' was best understood as a cover for other political struggles, opposing dominant political groups and their former dependents, and whose primary stakes were control over trade routes and access to pastures. Or they were seen as attempts to compensate for youth disaffection, the shortcomings of the state,

1 For critical comments on the concept of 'radicalisation', see Marchal and Ould Ahmed Salem 2018.

2 Lecocq et al. 2013. 
or indeed the effects of state corruption. ${ }^{3}$ While there can be no doubt about the much greater pertinence of these latter explanations, in both readings, 'radical Islam' risks being ultimately explained away. ${ }^{4}$ It appears either as foreign 'corruption' of local 'moderate' Islam, or as a smokescreen that can be overcome by the elimination of foreign fighters, military intervention, state building, and enhanced border control. In other words, experts might squabble over which level of analysis really matters - whether we are dealing with essentially local conflicts hiding behind an Islamic façade, or with another instance of the unchecked global march of religious fanaticism - but the basic terms of the debate are set, as is an implicit distinction between 'radical' and 'moderate' Islam. ${ }^{5}$

This chapter asks what would happen if we stepped back from this reading and took seriously the Islamic rhetoric put forward by various actors in northern Mali, situating it within a narrative not of radical rupture, but of continuity: within the tension between local conflicts and universal aspirations that have long shaped notions of justice, legitimacy, status, and belonging in the area, but that by definition can never be resolved. This is an undertaking beyond the scope of this chapter, or indeed the evidence at my disposal. ${ }^{6}$ Four tentative points emerge nonetheless: (i) Islamist activism in northern Mali situates itself neither on an exclusively local nor on a global scale, but derives its primary references, terms of debate, and recruits from a longstanding intellectual region that spans most (but by no means all) of the Western Sahara and its southern edge. (ii) This region provides Islamic movements in the area with their own historical and geographical framework that consciously predates contemporary nation-states, creating its own form of historicity and historical legitimacy. (iii) Within it, operative distinctions are not those of 'local' or 'foreign', but rather expressed in terms of status, kinship, and alliance. (iv) Lastly, religious

3 See Thurston and Lebovich 2013, Briscoe 2014, Raineri and Strazzari 2015, Benjaminsen and Ba 2019, Grémont 2019, Théroux-Benoni et al. 2016, Yahaya Ibrahim 2017, and Dowd and Raleigh 2013, respectively.

4 The tendency to explain religion through other factors has been built into the social sciences since Durkheim. Such explanations are important, but never quite sufficient (Schielke 2019).

5 As Prud'homme $(2015,131)$ notes, most academic analysts are wary of this distinction, which is clearly an etic (colonial), rather than an emic category. Given its current political force (Marzouki 2011), however, it is difficult not to play into it, willingly or not.

6 I carried out long-term ethnographic field research in northern Mali (mostly Gao and Timbuktu) in 2008 and 2009, but have not been back to the area since 2012, although I have spoken to people there on the telephone or met them elsewhere. This chapter is thus based on personal communications, written sources, and media and expert reports, in addition to my own background knowledge. 
differences, including those with people from southern Mali, do not necessarily indicate incompatibility, but potentially stake out new grounds for debate, thereby creating shared terms of references whose impact might be much greater in the long run than that of militant jihad. ${ }^{7}$

\section{The conflict}

In January 2012, fighters from the Mouvement National de Libération de l'Azawad (MNLA) successfully attacked several army garrisons in northern Mali. They met with little resistance as they advanced, taking Gao on March 31 and Timbuktu on April 1. On April 6, they announced (from Paris) the creation of the independent state of Azawad in northern Mali. By then, rebel forces controlled two thirds of Malian territory, although much of this was desert and home to less than ten per cent of Mali's overall population. In the meantime, the national government in southern Mali had collapsed following a military coup.

'Tuareg' rebellions have been an integral part of the country's history since independence from France in $1960 .{ }^{8}$ But they had never been quite as successful. This was partly due to the MNLA's much greater firepower compared to earlier rebel movements, which in turn was connected to Qadhafi's demise in neighbouring Libya, host to a substantial number of Malian Tuareg labour migrants. It can be partly explained by reference to the quasi-absence of state institutions in the North, which has long been governed by proxies. ${ }^{9}$ The MNLA, moreover, was not fighting alone in northern Mali, but was first seconded and then rapidly displaced by groups fighting under an Islamic banner. These included al-Qa'ida in the Islamic Maghreb (AQIM, a transformation of the Algeriabased GSPC), but also a number of more local groups, such as Ansar al-Din, and the Movement pour l'unicité et le jihad en Afrique de l'Ouest (MUJAO), who together seemed to be able to draw on a much more extensive pool of resources and recruits than the MNLA. After a short-lived alliance with the MNLA, these groups expelled MNLA officials from Timbuktu in April and from Gao in June 2012 and started to administer both towns and their hinterlands according to

7 As Li (2015, 12-7) notes, 'jihad' is a slippery term. However, the term and its derivatives are now widely used in Mali, including as a self-definition (Théroux-Benoni et al. 2016, 2), and I will follow this usage here.

8 See Boilley 2009 and Lecocq 2010.

9 Hüsken and Klute 2015. 
shari`a. In November 2012, the MUJAO also captured Menaka, thereby putting all major towns in the North under Islamist control.

On January 10, 2013, Ansar al-Din launched an attack on Konna, a town in central Mali south of the boundaries of 'Azawad'. Following a demand for help by the then Malian president Dioncounda Traoré, the French army intervened on January 11. Officially, this was an emergency intervention to stop 'jihadi terrorists' from reaching southern Mali, although their intervention had clearly been prepared beforehand, waiting for an opportunity to deploy. ${ }^{10}$ By the end of the month, the French army, with the help of Chadian troops, controlled all major settlements in northern Mali. They were gradually, but never totally, replaced by MINUSMA, a United Nations 'peacekeeping' mission, from April 25, 2013 onwards. ${ }^{11}$ At the time of final revisions (spring 2021), French troops were still on the ground in Mali, although resistance against their presence was mounting nationwide. ${ }^{12}$ Although external military intervention was swift in removing Islamist control from towns, and in killing perhaps a third of the estimated 2,000 fighters in the area, ${ }^{13}$ its control never extended to the countryside. Islamist groups of various labels and affiliations have since proliferated, including further south. Today, they control most of the rural areas in central and northern Mali, where they have implemented their own forms of territorial and legal administration, centred on wells, quranic schools, and Islamic courts. ${ }^{14}$

For international analysts, these events came as a shock. Mali had long been presented as the "poster child for African democracy"; ${ }^{15}$ a "donor darling"; $; 6$ poor, but friendly; a priced destination for tourists; culturally sophisticated, present on the international music scene; and, although Muslim, "tolerant" and

10 Henke 2017, 13. For more information on how and why the French intervention came about, see Henke 2017, and Boeke and Schuurman 2015. For an analysis of French military interventions in its former West African colonies more generally, see Charbonneau 2017.

11 'Peacekeeping' is a clear misnomer, as there was (and still is) no peace to be kept. On the MINUSMA, see Cold-Ravnkilde, Albrecht and Haugegaard (2017), who note internal structural inequalities between Western and non-Western soldiers. Soldiers from African countries account for $67 \%$ of military personnel on the ground, and for $90 \%$ of casualties so far.

12 See, for instance, https://www.youtube.com/watch?v=mbPaij780wo, accessed May 13, 2020. Also "Frappes sur Bounti (Mali): des associations demandent une enquête indépendante", RFI January 2, 2021; and "Mali: polémique autour d'une frappe de la force Barkhane vers Talataye”, RFI March 26, 2021.

13 Boeke and Schuurman 2015, 1.

14 Klute, personal communication, Bayreuth, March 4, 2019. See also International Crisis Group 2016 and 2019, 5 and 13.

15 Benjaminsen and Ba 2019, 5.

16 Bergamasci 2014. 
"open-minded"; "a peaceful republic with a pleasant air of democracy and secularism". ${ }^{17}$ As part and parcel of this image, 'Malian Islam' tended to be portrayed as inherently different from, and more 'tolerant' than, its Middle Eastern counterpart, in a rhetoric that echoed colonial distinctions between 'moderate' ('Sufi') and 'radical' ('Wahhabi'), 'local' and 'global', 'black' and 'white' Islam. ${ }^{18}$ 'The Tuareg', meanwhile, have long been seen by French audiences in particular as inherently 'un-Islamic', and open to friendship with France. ${ }^{19}$ There is no need to reiterate here that corruption had in fact been rife in pre-conflict Mali; that government in the North had been "mafia-like"; ${ }^{20}$ that Malian society was riven by generational, educational, regional, linguistic, and class tensions; that Islam in the country was as diverse and 'orthodox' as elsewhere; that Islamist groups from Algeria had long found a sanctuary in the north of the country, tolerated because Malian government officials collected a share of AQIM ransoms, much as they did with the profits of international smuggling in the area. ${ }^{21}$ That, in fact, Mali's golden international image was part of the problem, as Mali's dependency on foreign goodwill made it necessary to play up to whatever image 'the West' (or indeed, 'the East') wanted to see, instead of addressing political tensions in the country head-on.22

\section{Media portrayals}

Mali's golden image, including its alleged subscription to 'moderate Islam', however, was too deep-seated to be discarded quite so lightly. Initially, events in northern Mali were described primarily, in the media but also some expert reports, as sparked by external factors, by a heady cocktail of Algerian jihadis, Colombian drug-smugglers, and Libyan guns. ${ }^{23}$ Some of this might have been

17 Holder 2013.

18 'White' here refers to speakers of Tamacheq and Arabic. Triaud (2014) describes the colonial creation and the longevity of the notion of an 'African' or 'black Islam' that was perceived to be less 'pure' and therefore less threatening to European rule. Needless to say, this distinction is historically unfounded, as is the idea of a specifically 'Malian' or even 'African Islam' (Kane 2012).

19 Casajus 1995.

20 Bergamasci 2014, 355.

21 Dowd and Raleigh 2013, 506.

22 Bergamasci 2014, 348.

23 Briscoe 2014. 
due to the impact of French military propaganda. ${ }^{24}$ It is important to note here that the French military intervention in northern Mali resulted in a "war without images", ${ }^{25}$ or rather, one in which almost all information was produced or at least controlled by the French army. Subsequent analyses of the situation in northern Mali often read as if the French army itself were not themselves among the 'foreign actors' in the area, and the best-armed of them all. ${ }^{26}$ Whatever its origins, the image of an essentially external threat was endorsed by official Malian rhetoric pleading for foreign military intervention, and also by local actors who positioned themselves as bulwarks against 'global Islam'. Prominent among them was the late 'supreme chief' of the Touareg Kel Adagh in Kidal, Intallah ag Attaher, who, in 2013, asked "all armed movements from outside the Azawad” to leave; ${ }^{27}$ one of Intallah's sons, Alghabas, is currently administering Kidal based on shari`a. Beyond the control of major towns, foreign military intervention hence aimed primarily at the removal of foreign fighters and the closure of the border with Algeria and Niger, although these measures were rewarded with little success, beyond the increase of food prices for the local population. ${ }^{28}$

The image of jihadis as inherently alien to Mali also pervades popular portrayals of the current conflict in northern Mali, especially in Europe. Take, for instance, the 2014 film Timbuktu, a Franco-Mauritanian co-production directed by the Mauritanian filmmaker Abderrahmane Sissako. Timbuktu was acclaimed in French media as the "greatest success in the history of African cinema". ${ }^{29}$ It obtained seven Césars in 2015, including that of best film and best director, and it was the only African film officially selected for the 2014 Cannes film festival. It was filmed in Mauritania with funds from the Mauritanian government, and under protection and with logistical help from the Mauritanian and French armies. ${ }^{30}$ The film tells the story of a Tuareg couple and their daughter whose lives are torn apart as the husband, Kidane, accidentally kills a local fisherman. The fisherman's mother refuses to grant pardon, even though she is offered compensation. Kidane is condemned to death and executed by an Islamic legal

24 Henke 2017, 10.

25 Boeke 2016.

26 Grémont 2019, 49.

27 Lecocq et al. 2013, 11.

28 Bensassi et al. 2015, 19; see also "Entretien avec Alghabas ag Intalla, chef du Mouvement Islamique de l'Azawad (MIA)”, Malijet avec Andy Morgan Writes, February 1, 2013.

29 According to Radio France Internationale (RFI), February 3, 2016.

30 On Mauritania's ambivalent stance towards 'global Islamic terror', see Ould Ahmed Salem 2013. 
court. This story is based on the real execution of Moussa ag Mohamed, a Tuareg member of Ansar al-Din, judged and executed by his own friends and colleagues in November 2012. ${ }^{31}$ In the film, however, Kidane is a Tuareg herd owner and occasional musician unknown to, and inherently different from, the Islamists he confronts. The latter are mostly portrayed as foreign - the lead actor is Tunisian - and relying on interpreters to communicate with the local population. Or, they are 'up-rooted' locals who returned from exile in Libya and work in subordinate positions. No further mention is made of the refusal of the fisherman's family to forgive the murder and the way it probably contributed to the longstanding racial and ethnic tensions in the area.

This storyline is interspersed with re-enacted scenes from the Mauritanian journalist Lemine ould Mohamed Salem's (2016) documentary Salafistes, which condenses nine months of events across northern Mali into a few days in Timbuktu, and from news coverage. ${ }^{32}$ In the film's opening sequence, for instance, wooden statues looking generically 'African' are shot at by invisible mujahidin and ultimately destroyed. This seems to draw on "exclusive footage" broadcast by the French news programme Journal de 20 heures in June 2012, where local Tamacheq-speaking mujahidin are seen breaking small and rather badly made wooden statues and haranguing the local population. ${ }^{33}$ The status of these statues is unclear - "they probably took them from a tourist shop" ${ }^{34}$ - but the news commentary describes them as "traditional African divinities, broken one by one, just like the Taliban did with the famous Buddhas of Bamiyan, blown up with dynamite". ${ }^{35}$ (Timbuktu has been a centre of Islamic scholarship with an almost entirely Muslim population for centuries).

While there can be no common ground between 20 heures' statues and the Bamiyan Buddhas outside of Western perceptions of a universal threat, the parallel is significant. It feeds into the same underlying rhetoric about 'global jihad' that has been put forward since 2001 to justify the 'global war on terror' (GWOT). Namely, to blame it on a few inherently external agitators whose 'surgical' removal would return things back to normal. In Afghanistan, Iraq, and Syria, as it used to be in Chechnya and Bosnia Hercegovina, 'foreign fighters'

31 Lemine ould Mohamed Salem, "Dans le nord Mali, la charia s'applique aussi aux soldats de Dieu”, Libération, November 25, 2012.

32 Joan Tilouine, “'Salafistes': le documentaire qui a inspire 'Timbuktu’”, Le Monde, December 10, 2015.

33 Available from https://www.youtube.com/watch?v=YfheY-IGffQ, accessed March 11, 2019.

34 André Bourgeot, commentary on Timbuktu, available from https://www.youtube.com/ watch?v=UNJQxU7_7A, accessed March 11, 2019.

35 “Tombouctou, le carrefour des Salafistes d'Aqmi de par le monde”, 20 heures, June 9, 2012. 
tend to be represented as the most dangerous and 'fanatical' of all mujahidin in Western media. They are described as footloose and rootless, and hence without scruple and limitations; men without family nor women to bind them. They are, in Li's pithy phrase, "Muslims out of place", and in most cases in fact 'Arabs out of place'; they ought to be removed at all cost, and much of the worldwide military and punitive apparatus of the GWOT targets them as a priority. ${ }^{36} \mathrm{~A}$ story of 'Arabs out of place' in northern Mali is thus one that greatly resonates with Western and perhaps also some Malian audiences. It is, however, doubly pernicious as northern Mali is home to a small, but important, minority of Arabs, who, although Malian, are understood by many southerners to be inherently 'foreign', or at least, of questionable allegiance and loyalty to the Malian nation. ${ }^{37}$ Defining northern Malian Islamists as primarily Arab, and Arabs as foreign, feeds into a potentially explosive history of already fraught community relations.

\section{Islam as a façade for local conflicts}

Explanations emphasising the 'foreignness' of jihadis also stumble over empirical evidence showing that the majority of fighters were recruited locally and that local jihadi organisations occupied centre stage in the conflict. The more visible of these are Ansar al-Din, founded by Tuareg from Kidal but which also attracted a following among Arabs from Timbuktu, and MUJAO, said to be set up as a reaction against 'foreign' dominance of AQIM. It seems that the more spectacular jihadi activities dwelled on by foreign media, such as the destruction of saints' tombs, public flogging, amputations, and the prohibition of games, were carried out by local organisations and fighters, while the AQIM leadership attempted to calm their overzealousness in favour of a "progressive application" of shari ‘ $a$. AQIM in fact repeatedly cautioned their fighters against the "fanaticism" ( $t a$ 'assub, which is perhaps better translated as 'factionalism') of their Tuareg allies "which is only useful when it is well directed and ruled by law", admonishing them to be as inclusive as possible in their recruitment and counsel. ${ }^{38}$ As a result, more thoughtful analyses conclude that the conflict in

36 Li 2009, 359. Over two-thirds of the detainees at Guantanamo were foreign fighters (367).

37 Scheele 2013, 176.

38 AQMI, l'Emirat de l'Organisation, "Directives générales relatives au projet islamique djihadiste de l'Azawad”, July 20, 2012 (published by RFI, October 6, 2013). https://www.rfi.fr/ 
northern Mali was and is primarily local. ${ }^{39}$ Such analyses stress several elements: the long history of rebellion in northern Mali, the accumulated grievances this has led to, and the Malian government's repeated failure to address these; conflicts between groups considered to be a different status, ranging from 'noble' via 'client' to 'former slave'; competition over resources, both in the form of transnational smuggling and of pastoral and agricultural productive regimes; and local needs for protection, in an increasingly violent social and political environment.

Northern Mali has its own long and complex history of rebellion and bloody suppression by the Malian army. This in turn has created hostilities and a deepseated mistrust against the regime in Bamako and populations associated with it, as probably all 'white' inhabitants of the area - that is to say, Arabic- and Tamacheq-speakers of a higher status - have personal memories of brutal exactions committed by Malian soldiers, and lost close relatives in the struggle. ${ }^{40}$ It has also shaped the lives of many who are now prominent in armed conflict, such as, most famously, Iyad ag Ghali, the founder of Ansar al-Din and current leader of the JNIM, Mali's currently most influential Islamist movement, who had been an influential figure in earlier 'secular' rebellions. The rebellion of the 1990s and its aftermath was marked by scissions between different Tuareg groups, protesting against the dominant role played by 'noble' families in the 1990s rebellion and its aftermath. ${ }^{41}$ This was also the time when formerly subordinate groups started bearing arms. ${ }^{42}$ Similar explanations are now being put forward for the current conflict. Ansar al-Din is seen by some as an attempt, by former 'nobles', to re-ascertain their political leadership in the area. The creation of MUJAO tends to be interpreted as a reaction of 'southern Saharans' and former clients against the arrogance of the Algerian leadership of AQIM. ${ }^{43}$ In central Mali, the katiba Macina initially challenged the exclusive control of pasture by high-status local elites. ${ }^{44}$ More generally, cleavages often seem to follow divisions between status groups, although alliances remain unpredictable.

fr/afrique/20131006-mali-vade-mecum-droukdel-mali-aqmi-terrorisme-al-qaida-sanguinaire, accessed January 7, 2021.

39 For instance, Yahaya Ibrahim 2017, 8.

40 Locally, Europeans tend to be described as 'Christian' (nasara) rather than 'white'. On the use of colour terms (of which 'black' and 'white' are only two) to distinguish between groups of people in the region, see Hall 2011.

41 Klute 2011.

42 Grémont 2019, 53.

43 Raineri and Strazzari 2015, 259, Boeke and Schuurman 2015, 15.

44 Jourde, Brossier and Cissé 2019. 
Here as elsewhere, equality before God provides a persuasive argument for former lower-status people wishing to better their social position. Nonetheless, these explanations are only partly correct, as, true to the many cross-cutting ties that have long shaped the history of this region, ${ }^{45}$ leading regional figures tend to move from one group to another, to the point where "local people in northern Mali are themselves unable to determine which group is which". ${ }^{46}$ Islamists, meanwhile, put forward a message of inclusivity: "Our battle is in the name of Islam, it's not Arab or Tuareg, black or white, it's in the name of Islam". ${ }^{47}$ This might be propaganda, but it is also, realistically, the only path to long-term military and political success in the area. The AQIM leadership at least are clearly aware of this - indeed, as seen above, excessive 'tribalism', or ta' $a s s u b$, is one of their recurrent bugbears. Meanwhile, factional readings of events tend to become self-fulfilling prophecies, as the Malian government pursues its longstanding strategy of arming some groups against others, or of creating 'local militias' that, statistically speaking, have by now killed more people than any other actor in the Malian conflict, including the Malian and French armies..$^{48}$ Again, this strategy has a long and brutal history in the area.

Another related set of analyses, which have gained increased traction in the past few years as jihadis have successful spread into central Mali, draw on political economy. After interviews with sixty-three "previously involved" young men in central and southern Mali, Théroux-Benoni et al. conclude that

in most cases documented by this study, youth engagement did not hinge on religious factors and was not the result of religious indoctrination. Religion seems to play a marginal position in the motivations of the youths interviewed in this study. ${ }^{49}$

Rather, what mattered most to people was a desire to protect themselves and their livelihoods, especially in the area around Mopti, where membership in a jihadi group was seen as effective protection against cattle rustling.

In a similar vein, Poupart explains the constitution of the MUJAO in Gao as an attempt by locals to protect themselves against MNLA exactions: all political groups in the area "act like entrepreneurs and propose different types of rhetoric

45 Grémont et al. 2004.

46 Abu Ibnein, "Oumar Ould Hamaha: a case study of the bridges between three groups", GCTAT, 11/01/2013. http://www.gctat.org/fr/analysis/29-ranoc/220-oumar-ould-hamaha-a-casestudy-of-the-bridges-between-three-groups.html, accessed January 7, 2021.

47 Oumar ould Hamaha, Timbuktu, April 6, 2012, recorded by AFP.

48 Boisvert 2015, International Crisis Group 2016, 2019, Human Rights Watch 2020.

49 Théroux-Bénoni et al. 2016, 4. 
that mobilise to different degrees and according to their own strategies, identity, and political and religious aspirations". ${ }^{50}$ Grémont traces the history of conflicts and alliances open to local groups in north-eastern Mali and concludes that those who opt for Islamist allegiances "certainly do not primarily aim to carry out universal jihad", but rather draw on them "as a resource in struggles for local power", much as others might draw on privileged links with the French army. ${ }^{51}$ For Benjaminsen and Ba, who also work on central Mali, "alliances and conflicts are structured by material interests with deep historical roots in controlling land and resources, rather than by a radical Islamist agenda". ${ }^{52}$ Local Fulani join Islamist groups because they provide reliable, quick, and relatively cheap solutions to struggles over land-rights, because they fight against extortion by noble groups traditionally backed by the state, and because they protect members against attacks by sedentary Dogon self-defence groups trained by the Malian army.

\section{Arabs out of place?}

My aim here is not to show that this point of view and the analyses that it informs are substantially wrong (they are not), but rather that because of the need to counterbalance media reports on 'foreign contamination' they may be wilfully blind to regional connections and universal ideas that also matter. As Grémont himself notes, as soon as the parties to local conflicts refer to their opponents as 'mujahidin' or 'collaborators with the French', simply speaking of inter-community conflicts "is perhaps not wrong, but certainly reductive". ${ }^{53}$ Indeed, attempts to avoid the narrative of 'global jihad' at all cost might implicitly strengthen it, by endorsing the conceptual division between 'local' and 'global' factors, while weighing them differently. In northern Mali (as elsewhere), local conflicts are rarely experienced as just local. To say that they might be phrased in, or rather experienced through, universal religious terms, and sincerely so, does not invalidate their local impact, on the contrary: both levels mutually reinforce each other, and give each other additional meaning. Quranic notions of injustice, tyranny, and the abuse of power strike chords with people who suffer from these daily, and gain clarity and traction from universal

50 Poupart 2017, 105 and 102.

51 Grémont 2019, 58 and 60.

52 Benjaminsen and Ba 2019, 4. Jourde, Brossier and Cissé 2019 make a similar argument.

53 Grémont 2019, 47. 
language. Conversely, it is difficult to imagine what a 'radical jihadi agenda' that could not feed on local conflicts and specific resentments would in fact look like. It is thus this articulation of different levels, rather than the assumed preponderance of one over the other, that should catch our attention. This kind of 'scaling' has a long history in the region. Today, it is employed on all sides of the Malian conflict, although the universal values invoked vary.

On August 22, 2016, Ahmad al-Faqi al-Mahdi, member of Ansar al-Din, was brought to trial before the ICC, accused of war crimes by the Malian government. He was indicted for leading the destruction of nine shrines and parts of the Sidi Yahya mosque in Timbuktu, one of which was a UNESCO-certified World Heritage site. ${ }^{54} \mathrm{He}$ was sentenced to nine years in prison and to pay $€ 2.7$ million in compensation to his victims. According to the then director general of UNESCO, Irina Bokova, “[w]hen a World Heritage site is destroyed, because of stupidity and violence, the whole of humanity feels that it has been deprived of part of itself; that it has been injured." 55

Islamic groups are thus not the only ones to invoke universal values to describe local events. And, for UNESCO also, the universal always necessarily takes place somewhere, and hence partakes in local socio-economic and political conflicts. By 2015, the shrines had been re-built with UNESCO funding, and "a ceremony was held... to reconsecrate [sic] the sites and hand back the keys to their traditional owners". ${ }^{56}$ Buildings that, from a UNESCO point of view, look like universal heritage were, in Timbuktu itself, closely associated with particular families, descendants of the saints; UNESCO therefore intervened - unwittingly but unavoidably - in power relations on the ground.

These families still exercise influence and claim superior status in the area, a claim that is resented by many. Thus, local Islamists reject the veneration of saints both in terms of a universal principle and in terms of a personal relationship of expected subordination to a particular family, and a hierarchical system associated with their high status. Most (but by no means all) jihadis or other kinds of Islamists recruited in Timbuktu are from groups that cannot claim privileged access to prestigious religious ancestry. This does not mean that we can reduce their motivation solely to local status struggles. Nevertheless, aspirations for universal value systems tend to appeal to people on the basis of their own experience. Similarly, Algerian Islamist who settled in the area from the

54 https://www.icc-cpi.int/Pages/item.aspx?name=pr1154\&ln=en, accessed March 26, 2021. 55 https://whc.unesco.org/en/news/987;\%20consulted\%20March\%2026,\%202021, accessed March 26, 2021.

56 Joy 2018. 
1990s onwards tended to intermarry with families of lower status. Their in-laws thereby gained access to other forms of wealth, but also to a different kind of religious legitimacy - a different kind of universalism than that represented by the saints and their tombs and descendants. This can be read both as an attack on a social system based on genealogical status, and as an attempt to diversify it by introducing new sources of prestige. We are, then, not dealing with the opposition of local to global, but rather with the tensions between different claims to universality.

Timbuktu saints, moreover, tend to be internationally recognised Islamic scholars, and are therefore by definition never just local. A brief look the names of the saints whose tombs have been destroyed gives us an indication of their heterogeneity, as well as of their ambivalent geographical status. They are: Sīdi Mahmūd b. 'Umar Aqīt (al-Walātī, from present-day Mauritania); Shaykh Muhammad Mahmūd al-Arawānī (just north of Timbuktu; the family claims Moroccan and ultimately sharifian origin); Shaykh Mukhtār b. Sīdi Muhammad b. Shaykh al-Kabīr (al-Kuntī, from present-day southern Algeria); Alpha Moya; Sīdi Mahmūd b. 'Ammār (al-Walātī, from present-day Mauritania); Shaykh Muhammad al-Makkī (from the Hijāz); Shaykh 'Abd al-Kasim al-Tuwātī (from present-day southern Algeria); Ahamad Fūlān; Bahaber Babadié; Sīdi Yahya (alAndalūsī). Their status as 'saints' owes much to their distant origins. It derived from their ability to reinvent the local through universal categories of value, and to inscribe the city into regional networks of scholarship, religious legitimacy, and mobility. Put together, their places of origin sketch out a region of religious connectivity that still has significance today, and indeed echoes contemporary jihadi talk, activity, and recruitment.

Ahmad al-Faqi, meanwhile, described himself as "a Tuareg born in a village near Timbuktu" ${ }^{\text {"7 }}$ - one of the many lower-status 'whites' who, since the 1990s, felt excluded from the urban centre of Timbuktu..$^{58}$ Rather than a foreign jihadi attacking local saints, he is a local, or rather suburban, jihadi attacking 'foreign' saints in the name of the same universal religion that grants the latter their local precedence. Meanwhile, those saints and their contemporary descendants have found an unlikely backer in UNESCO, another universalist moral body, but one that comes with finance and court orders attached. In other words, Ahmad al-Faqi's opposition to the local saintly families was probably simultaneously religiously, historically, socially, and politically motivated, and Bokova's "whole of humanity" was only one of his targets. Similarly, when MUJAO destroyed a

57 Joy 2018, 15.

58 Scheele 2013, 175-76. 
shrine $330 \mathrm{~km}$ north of Gao, it was a Kunta shrine. ${ }^{59}$ This could be read as an act of religious purification, but also as the last instalment in the 'Kunta war', waged by formerly lower-status Arabs against their Kunta 'lords' ${ }^{60}$ The overwhelming historical reference underlying many of these conflicts makes their religious scaling eminently plausible, but it would be wrong to privilege one level over another.

\section{In-laws and out-laws}

What, then, if we stepped away from oppositions between local and global, national and foreign, or even from formulations that try to dodge the question through neologisms, such as "glocal"? ${ }^{61}$ It is not merely the empirical inadequacy of this opposition that is at stake here, but also its conceptual limits. "The global" is all too often used "lazily as a catch-all appellation for things that are not readily understood in local or national terms". ${ }^{62}$ The local raises just as many questions, especially when it comes to Islam, which, as a revealed religion, by definition implies some reference to the outside. This is true everywhere, but perhaps even more so in places like northern Mali, where people tend to be mobile, intermarry and trace relationships in other than national categories; where indeed mobility and a certain degree of externality tends to be at the root of local influence. ${ }^{63}$ As a result, distinctions between 'local' and otherwise are gradual, contextual, and might change over a lifetime. Within the current conflict also, it is difficult to distinguish between local and global organisations. As noted above, people change allegiance, acronyms develop, and the exact interrelation between different groups remains obscure, perhaps even for those within them. Many, if not most, prominent fighters and politicians in the area have been members of at least three, and sometimes even four or five different groups that analysts might locate on different sides of the local and global (or indeed the 'religious' and 'secular') divide. ${ }^{64}$ They also tend to speak several languages, and have a wide set of family connections to choose from.

59 Raineri and Strazzari 2015, 261.

60 On the Kunta war, see Scheele 2009, 86.

61 Marret 2008.

62 Li 2015, 17.

63 Scheele 2012, chapter 4.

64 Boeke 2016, 915. 
The second problem with the categorical opposition between the local and the global is that it does not allow for intermediate levels of analysis. It is telling that Islamist references to regional projects are often transformed into a "global agenda" by analysts, ${ }^{65}$ true to Li's observation that there is a general "blindness" among analysts "to the possibility that others may pursue substantively different cosmopolitan or transnational projects". ${ }^{66}$ On closer examination, however, groups like AQIM, notwithstanding their claims to a 'global jihad', are neither local nor global in their activities, recruitment, and intellectual and historical references, but regional. The region they operate in pre-dates not only their existence, but also that of the nation-states they are fighting against. It is, in fact, similar to the one staked out by the nisab of the saints listed above, and replicated in generations of exchange, pilgrimage, travel, and intermarriage since their demise.

AQIM and other jihadi groups in the area have mostly fought and claimed attacks carried out within a territory ranging from Algeria to Mauritania via northern Mali, Burkina Faso, and Niger. Their recruits, if they are 'foreign', similarly stem from that area, more precisely from Algeria, northern Mali and Mauritania, with the occasional Nigerian and Tunisian put in for good measure. This is not for lack of trying to attract people from elsewhere, but few international jihadis really want to go and fight in Mali when there are more attractive and prestigious options elsewhere. AQIM hence attempted to encourage more Tunisians to join them, but although Tunisians constituted the second largest contingent of foreign fighters in Iraq and Syria, and the majority in Libya, few were willing to travel to Azawad. ${ }^{67}$ Libyans and Moroccans similarly have never shown much interest in AQIM, which retained close links with its Algerian origins. ${ }^{68}$ Moreover, their "Saharan brigade" does not seem to be recruited from the whole country, but rather from the northern edge of the deserts, a region that is historically closely connected to the deep south of Algeria and Azawad. ${ }^{69}$ Abu Zeid, for instance, was born in the Illizi region, while Mokhtar Belmokhtar is a Sha'anba from near Ghadaïa, a group prominent among the regional trading elite since colonial times. When MUJAO fighters resented the influence of 'northern Saharans', these were perhaps the people they meant, and their re-

65 See e.g. Guidère's summary of an interview with the leader of AQIM, Abdemalek Droukdel, published in the New York Times, July 1, 2008, in Guidère 2008.

66 Li 2009, 426.

67 Boeke 2016, 924.

68 Filiu 2009, 225.

69 Scheele 2012, chapters 1 and 2. 
sentment was thus historically complex: they had long known the people they were dealing with, or at least their families, as regional traders, patrons, and inlaws.

If this seems anecdotal, it is striking that until 2012, the most common idiom used by Arabic-speakers in northern Mali when talking about 'jihadis' were those derived from kinship and alliances, rather than from categorical distinctions between local and foreign: "they came and got married to Arabs and Tuareg of no account out in the desert”. The local AQIM leadership followed suite, getting married to families of somewhat more account. Or, as Lecocq put it, the Saharan "foreign fighters" were "not so much foreign as they are simply choosing between nationalities, while sometimes holding multiple ones" ${ }^{70}$ This rhetoric is worth pursuing, not only because it replaces absolute categories (foreign and local) with relative ones (in-laws), and categorical oppositions with nuanced histories of alliance and rivalry, but also because it underlines the role of women who, as a result, act as indispensable mediators and conduits for external ideas and agents, and their moral evaluation, and vice versa. ${ }^{71}$

\section{Different cosmopolitan projects}

This region of jihadi involvement and recruitment is also reflected in its historical references. These need to be taken seriously as the expression of a particular way of making sense of the world, steeped in regional history and geography. This is apparent in the names chosen for local katā'ib (brigades, singular katība), which include (among others) AQIM's katība Tāriq b. Ziyād, named after the Umayyad commander (of Berber or Arab origin) who led the conquest of Visigothic Hispania in the $8^{\text {th }}$ century, and katība Yūsuf b. Tashfinn, third Almoravid imām and founder of Marrakesh in the $11^{\text {th }}$ century; AQIM's splinter group al-Murābitūn (the Almoravids, a reformist movement of Berber origin); and MUJAO's katība Usman dan Fodio (a militant $18^{\text {th }}$-century Islamic reformer).$^{72}$ In central Mali, the Front de Libération du Macina (FLM, or katība Macina) refers, in name but also in its internal jurisprudence, to the Dina (jihadi state) of Hamdallahi that governed the area in the $19^{\text {th }}$ century; conflicts over pastures

70 Lecocq 2013, 66.

71 Personal observations; Goundam and Timbuktu, 2007-08. Women are prominent in Islamic reform movements throughout the Sahel: see for instance Holder 2012 on southern Mali, and Sounaye 2011 on Niger.

72 A common reference also among Islamic reformers in Niger, see Sounaye 2012. 
are regulated with reference to Dina precedent, adapted to suit many of their followers' more egalitarian ambitions. ${ }^{73}$

In their internal correspondence, AQIM leaders describe the population of Azawad as eminently qualified for jihad, despite contemporary shortcomings,

because this people has distinguished itself by its commitment to the Islamic conquest under the Almoravids who have long preserved and defended the umma. It is one of the Islamic fighting people and will defend Islam and bear the responsibility for this region in the future. ${ }^{74}$

This telescoping of history also influences AQIM's sociology, viewing the "people of Azawad" as divided into minor and major tribes and "social layers". This might strike us as anachronistic, but it is in the nature of political projects to impose their own historicity and thereby their own conceptual frameworks through which action is made meaningful. In northern Mali, this historical and sociological vision - and also the apparent anachronism or "self-conscious archaism" that underpins $\mathrm{it}^{75}$ - might be off the mark at times, but is partly shared locally, and in fact results in a political programme that corresponds more closely to local political realities than Malian nation-state visions ever did. Tribes matter locally, as do genealogies and quranic history; ${ }^{76}$ they do not fix people's relations in time, but provide a powerful grid of interpretation that cannot easily be rejected out of hand - names, categories, moral judgments and causal relations borrowed from it have much resonance.

The historical regions thus described by different groups and actors do not necessarily overlap. Reference to historic Sahelian jihads imply a different vision of space than reference to the Almoravids and al-Andalus (as AQIM's media outlet is called). But they are regions of a similar kind. They have no borders, but shared reference points, and establish a "new political geography (...) organized around sites of militancy and Muslim suffering" 77 and more visibly in this context, around sites of former glory and triumph. The absence of borders, and the associated free circulation of goods and people is indeed one of the positive aspects of jihadi rule that people emphasise locally. It is exactly the opposite to

73 Benjaminsen and Ba 2019, 13, International Crisis Group 2019, 19.

74 AQIM, l'Emirat de l'Organisation, "Directives générales relatives au projet islamique djihadiste de l'Azawad”, July 29, 2012 (published by RFI, October 6, 2013). https://www.rfi.fr/ fr/afrique/20131006-mali-vade-mecum-droukdel-mali-aqmi-terrorisme-al-qaida-sanguinaire, accessed January 7, 2021.

75 Creswell and Haykel 2015, 107.

76 Scheele 2012, chapter 4; see also Popenoe 2004, 56.

77 Creswell and Haykel 2015, 105. 
international interventions whose main goal, as seen above, often seems to be to close borders and immobilise people. Both of these statements are ideological rather than empirical, as borders are never completely closed, and circulation is never free for all; but their ideological and symbolic impact matters. One of the first things MUJAO did was to abolish import and export tariffs, and while this might be a windfall for traders, it indirectly benefitted everybody in the region.

Jihadis, moreover, are not the only Islamic organisations to function in a regional transnational space that is broader than the nation-state (and might in fact exclude parts of it), without thereby being global. Holder describes the geographical reference relevant to the southern Malian reformist association Ançar Dine (not to be confused with the northern Ansar al-Din), which ends at Mopti - not coincidentally on the former border of Azawad - but extends across Mandé-speaking areas in Burkina Faso and Côte d'Ivoire. Holder labels this "a West African umma" ${ }^{78}$ Such regional distinctions do not preclude dialogue, and their boundaries are fluid over time. As Li noted (with Afghanistan in mind), they might in fact generate pan-Islamism: everybody who defines themselves as a Muslim can choose to gather under the banner of Islam in certain circumstances, and the important question is not how uniformity remains necessarily elusive, but how differences are dealt with. ${ }^{79}$ Even disputes can bring people together, as they might be grounded in shared assumptions and thereby reinforce them.

In the same way, the boundaries of 'Azawad' in no way indicate those of religious debate. Commentators have made much of the fact that Mahmoud Dicko, head of Mali's Haut conseil islamique du Mali (HCIM) and himself a native of Timbuktu, initially welcomed the instauration of shari $a$ in northern Mali, before retracting his statement under international pressure. ${ }^{80}$ It is difficult to see how he could be against shari $a$ (although he can of course be against its 'abuse', or against jihad, which he has since described as a "French creation"). ${ }^{81}$ Dicko himself is an Islamic reformer, one of many, and there has been a general shift in the Sahel towards a changed understanding of Islam, a "Salafi revolution" in Sounaye's words, which has led not so much to (yet another) split between 'moderate' and 'radical' Islam, but to a change of generally accepted

78 Holder 2012, 405.

79 Li 2012, 19.

80 On Dicko's consummate negotiation skills with Western media, see Prud'homme 2015.

81 https://mondafrique.com/le-chef-religieux-du-mali-denonce-le-djihadisme-comme-unecreation-francaise/, accessed March 11, 2019. 
Islamic rhetoric and standards. ${ }^{82}$ Or, in Alghabas ag Intallah's terms, "whoever speaks here now, in this territory, cannot say that they are against Islam". ${ }^{83}$ This means that people might emphatically condemn the violent means employed by jihadis in northern Mali, without rejecting their underlying principles, many of which have in fact become common sense. This is why, in Bamako, the term 'terrorist' is more often applied to 'Tuareg separatists' than Islamists, and many feel that it would be easier to negotiate with Islamist groups - who are Muslim after all - than with, say, 'the Tuareg, ${ }^{84}$ Conversely, Dicko has been named recently by the leader of the katîba Macina in central Mali as one of three prominent Malian Muslim figures with whom dialogue might be possible. ${ }^{85}$

\section{Conclusion}

Much has been written about Islam in northern Mali since 2012. This chapter has attempted to summarise some of this literature and to point to a number of common assumptions that seem to underpin much of it. 'Radical Islam' tends to be portrayed either as alien to Mali, brought by 'foreign fighters', familiar to Western audiences from conflicts elsewhere. Or it is seen as a stratagem adopted by locals to give greater resonance to their own interests. Many of the latter explanations are valid, but they seem insufficient to fully explain the appeal of Islamic rhetoric in the area. Nor do oppositions between local and global (and 'political' or 'religious') factors necessarily exhaust possibilities on the ground. This chapter argued that tensions between local and universal principles have always been part of Islam in the region, and indeed account for much of its vitality; and that they have contributed to shaping an intermediate, regional level that is most relevant to contemporary jihadis. This region is not necessarily one bound by peace and harmony, or indeed by perceived homogeneity. Instead, it is held together by genealogical links and the many possible shades of kinship and status that they imply. In such a context, a vocabulary derived from kinship and alliance, rather than from national and international politics, might be more in tune with the empirical evidence. Those people locally who most

82 Sounaye 2017. Holder $(2013,149)$ speaks of a "strategy of normalisation of Salafism”, Østebø $(2015,15)$ of the emergence of a "Salafi moral economy".

83 Alghabas ag Intalla, chef du Mouvement Islamique de l'Azawad (MIA). Malijet avec Andy Morgan Writes, February 1, 2013.

84 Whitehouse 2018, 172 and 175.

85 International Crisis Group 2019, 16. 
fully master these complexities, and can partake in them all, are in fact those who have most benefitted from the current situation. The late Intallah's family in Kidal are perhaps the best example of this. Due to their judicious involvement in the MNLA and Ansar al-Din, combined with negotiations with the French and the Malian government, they are now by all accounts running the place according to their own version of shari ${ }^{`} a .^{86}$

86 Georg Klute, personal communication March 4, 2019, Bayreuth. 


\section{Bibliography}

Benjaminsen, Tor, and Boubacar Ba. 2019. "Why do pastoralists in Mali join jihadist groups? A political ecological explanation." Journal of Peasant Studies 46, no. 1: 1-20.

Bensassi, Sami, Anne Brockmeyer, Matthieu Pellerin, and Gaël Raballand. 2015. "Commerce Algérie-Mali. La normalité de l'informalité." Washington: World Bank.

Bergamasci, Isaline. 2014. "The fall of a donor darling: the role of aid in Mali's crisis." Journal of Modern African Studies 52, no. 3: 347-78.

Boeke, Sergei. 2016. "Al Qaeda in the Islamic Maghreb: terrorism, insurgency, or organized crime?" Small Wars and Insurgencies 27, no. 5: 914-36.

Boeke, Sergei, and Bart Schuurman. 2015. "Operation 'Serval': a strategic analysis of the French intervention in Mali, 2013-2014." Journal of Strategic Studies 38, no. 6: 801-25.

Boilley, Pierre. 2009. Les Touaregs Kel Adagh. Dépendances et révoltes: du Soudan français au Mali contemporain. Paris: Karthala.

Boisvert, Marc-André. 2015. "Failing at violence: The longer-lasting impact of pro-government militias in northern Mali since 2012." African Security 8, no. 4: 272-98.

Briscoe, Ivan. 2014. "Crime after jihad: armed groups, the state and illicit business in postconflict Mali.” CRU Report.

Casajus, Dominique. 1995. "Les amis français de la cause touarègue." Cahiers d'études africaines 35, no. 1: 237-50.

Charbonneau, Bruno. 2017. "De Serval à Barkhane: les problèmes de la guerre contre le terrorisme au Sahel." Les temps modernes 693-694, no. 2-3: 322-40.

Cold-Ravnkilde, Signe, Peter Albrecht, and Rikke Haugegaard. 2017. "Friction and Inequality among peacekeepers in Mali." RUSI Journal 162, no. 2: 34-42.

Creswell, Robyn, and Bernard Haykel. 2015. "Battle lines. Want to understand the jihadis, Read their poetry." The New Yorker, June 5 and 8, 2015: 102-7.

Dowd, Caitriona, and Clionadh Raleigh. 2013. "Briefing: the myth of global Islamic terrorism and local conflict in Mali and the Sahel." African Affairs 112, no. 448: 498-509.

Filiu, Jean-Pierre. 2009. "The local and global jihad of al-Qa'ida in the Islamic Maghreb." Middle East Journal 63, no. 2: 213-26.

Grémont, Charles. 2019. "Dans le piège des offres de violence. Concurrences, protections et représailles dans la région de Ménaka (Nord-Mali, 2000-2018)." Hérodote 172, 43-62.

Grémont, Charles, André Marty, Rhissa ag Moussa, and Younoussa Hamara Touré. 2004. Les liens sociaux au Nord-Mali. Entre fleuve et dunes. Paris: Karthala.

Guidère, Mathieu. 2008. "La tentation internationale d'Al-Qaïda au Maghreb islamique.” Focus stratégique 12.

Hall, Bruce. 2011. A history of race in Muslim West Africa, 1600-1960. Cambridge: Cambridge University Press.

Henke, Marina. 2017. "Why did France intervene in Mali in 2013? Examining the role of intervention entrepreneurs." Canadian Foreign Policy Journal 23, no. 3: 307-23.

Holder, Gilles. 2012. "Chérif Ousmane Madani Haïdara et l'association islamique Ançar Dine." Cahiers d'études africaines 206-7: 389-425.

Holder, Gilles. 2013. “'Mon pays S.A.': un certain retour sur la démocratie exemplaire du Mali et sa déraison islamique." Dossiers du CERI (juillet 2013).

Human Rights Watch. 2020. “'Combien de sang doit encore couler?’ Atrocités commises contre les civils dans le centre du Mali, 2019.” HRW, February 2020. 
Hüsken, Thomas, and George Klute. 2015. "Political orders in the making: emerging forms of political organization from Libya to northern Mali." African Security 8, no. 4: 320-37.

International Crisis Group. 2016. “Central Mali: an uprising in the making?” Africa Report 238, July 6, 2016.

International Crisis Group. 2019. "Speaking with the 'bad guys': towards dialogue with Central Mali's Jihadists." Africa Report 276, May 28, 2019.

Jourde, Cédric, Marie Brossier, and Modibo Ghaly Cissé. 2019. "Prédation et violence au Mali: élites statutaires peuls et logiques de domination dans la région de Mopti." Canadian Journal of African Studies 53, no. 3: 431-45.

Joy, Charlotte Louise. 2018. “Crimes against cultural heritage in Timbuktu." Anthropology Today 34, no. 1: 15-16.

Kane, Ousmane. 2012. “L'islamisme' d'hier et d'aujourd'hui. Quelques enseignements de l'Afrique de l'ouest." Cahiers d'études africaines 52, no. 2-3: 545-74.

Klute, Georg. 2011. "From friends to enemies: negotiating nationalism, tribal identities, and kinship in the fratricidal war of the Malian Tuareg." Année du Maghreb 7: 163-75.

Lecocq, Baz. 2010. Disputed desert: decolonisation, competing nationalisms and Tuareg rebellions in Mali. Leiden: Brill.

Lecocq, Baz. 2013. "Mali: this is only the beginning." Geographical Journal of International Affairs 14: 59-70.

Lecocq, Baz, Gregory Mann, Bruce Whitehouse, Dida Badi, Lotte Pelckmans, Nadia Belalimat, Bruce Hall, and Wolfram Lacher. 2013. "One hippopotamus and eight blind analysists: a multivocal analysis of the 2012 political crisis in the divided Republic of Mali. Extended Editors' Cut." ROAPE 137.

Li, Darryl. 2009. “A universal enemy?: 'foreign fighters' and legal regimes of exclusion and exemption under the 'global war on terror'." Columbia Human Rights Law Review 41: 355427.

Li, Darryl. 2012. "Taking the place of martyrs: Afghans and Arabs under the banner of Islam." Arab Studies Journal 20, no. 1: 12-39.

Li, Darryl. 2015. “A Jihadism anti-primer.” Middle East Report 276: 12-17.

Marchal, Roland, and Zakaria Ould Ahmed Salem. 2018. “La 'radicalisation': aide-t-elle à mieux penser?" Politique africaine 149: 5-20.

Marret, Jean-Luc. 2008. "Al-Qaeda in the Islamic Maghreb: a 'glocal' organization." Studies in Conflict and Terrorism 31, no. 6: 541-52.

Marzouki, Nadia. 2011. "De l'endiguement à l'engagement: le discours des think tanks américains sur l'islam depuis 2001." Archives de sciences sociales des religions 155, no. 3: 2139.

$\emptyset$ stebø, Terje. 2015. “African Salafism: religious purity and the politicization of purity.” Islamic Africa 6, no. 1-2: 1-29.

Ould Ahmed Salem, Zakaria. 2013. Prêcher dans le désert: islam politique et changement social en Mauritanie. Paris: Karthala.

Popenoe, Rebecca. 2004. Feeding desire. Fatness, beauty, and sexuality among a Saharan people. London: Routledge.

Poupart, Pauline. 2017. “'L’Azawad comme enjeu de négociation de paix au Mali: quel statut pour un territoire contesté?” Confluences Méditerranée 101: 97-112.

Prud'homme, Pierre. 2015. "L'imam, l'expert et le diplomate: retour sur une recherche au Haut Conseil Islamique du Mali." Civilisations 64, no. 1-2: 129-40. 
Raineri, Luca, and Francesco Strazzari. 2015. "State, secession and jihad: the micropolitical economy of conflict in northern Mali." African Security 8, no. 4: 249-71.

Scheele, Judith. 2009. "Tribus, états et fraude: la région frontalière algéro-malienne." Études Rurales 184: 79-94.

Scheele, Judith. 2012. Smugglers and saints of the Sahara: regional connectivity in the twentieth century. Cambridge: Cambridge University Press.

Scheele, Judith. 2013. "A pilgrimage to Arawān: religious legitimacy, status and ownership in Timbuktu." American Ethnologist 40, no. 1: 165-81.

Schielke, Samuli. 2019. "The Power of God: four proposals for an anthropological engagement." ZMO Programmatic Texts no. 13.

Sounaye, Abdoulaye. 2011. “'Go find the second half of your faith with these women!': women fashioning Islam in contemporary Niger." The Muslim World 101, no. 3: 539-54.

Sounaye, Abdoulaye. 2012. "Heirs of the Sheikh. Izala and its appropriation of Usman dan Fodio in Niger." Cahiers d'études africaines 52, no. 2-3: 427-47.

Sounaye, Abdoulaye. 2017. "Salafi revolution in West Africa." ZMO Working Papers no. 19.

Théroux-Benoni, Lori-Anne, William Assanvo, Ibrahim Maïga, Jeannine Ella A Abatan, Fatimata Ba, Patrick Olivier Gnonsekan, Aïssatou Kanté, Kadiatou Yacouba Keïta, Wendyam Aristide Sawadogo - along with Modibo Galy Cissé, Aboubacar Diallo, Bréma Ély Dicko, Amadou dit Samba Cissé, Yacouba Dogoni, Fodié Tandjigora, and Aly Tounkara. 2016. "Mali’s young 'jihadists'. Fuelled by faith or circumstance?” Policy Brief 89, Institute for Security Studies.

Thurston, Alexander, and Andrew Lebovich. 2013. "A handbook on Mali’s 2012-2013 crisis.” Institute for the Study of Islamic Thought in Africa, Working paper series 13-001.

Triaud, Jean-Louis. 2014. "Giving a name to Islam south of the Sahara: an adventure in taxonomy." Journal of African History 55, no. 1: 3-15.

Whitehouse, Bruce. 2018. "Public perceptions of violent extremism in Mali." In African Border Disorders: addressing transnational extremist organizations, edited by Olivier Walther, and William Miles, 170-86. London: Routledge.

Yahaya Ibrahim, Ibrahim. 2017. "The wave of jihadist insurgency in West Africa: global ideology, local context, individual motivation.” University of Florida: Sahel Research Groups. 
